\title{
The carbon emissions of selected airlines and aircraft types in three geographic markets .
}

\author{
C Miyoshi and K J Mason* \\ Business Travel Research Centre, \\ Air Transport Dept., Cranfield University, Cranfield, MK43 0AL, UK
}

\begin{abstract}
:
Various carbon calculators developed by airlines and carbon offset companies have become available since the environmental impact of the air transport industry started to receive strong attention. This paper details a prototype methodology for carbon calculation emissions levels in the three air transport markets; the UK domestic routes, the intra-EU routes serving UK and the North Atlantic routes that enables the assessment of key environmental performance differences between air carriers whereas they would be measured as identical using the often used DEFRA-type measurement approach. The results shows differences in airlines' strategies such as aircraft type used, load factors and seat configurations.
\end{abstract}

Keywords: Environment, carbon calculator methodology, business travel, airline business models.

\section{Introduction}

Business related travel accounts for around $40 \%$ of all air trips (Doganis, 2002,). While the very rapid growth of leisure travel on mainly low cost carriers has reduced the proportion of business travel for European short haul travel, business travel is still growing at around 5\% a year (Mason and Alamdari, 2007). As corporate social responsibility (CSR), and the environmental impact of businesses on local communities and globally has risen up corporate executive agendas, companies are increasingly looking for ways in which to lighten their businesses carbon emissions levels. Moreover, companies that can demonstrate to their clients that they minimise and mitigate their environmental impact may benefit from competitive advantage over their competitors. For many companies, business related air travel is a significant contributor to their carbon footprints and thus one way to reduce carbon emissions is to look to better manage their use of air travel. To do this, companies need to be able to assess the environmental performance of individual airlines and different airline business models to be able to make better-informed choices in their purchasing and procurement processes. Current carbon calculators as proposed by UK government's Department of the Environment, Food and Rural Affairs (DEFRA) based on a simplistic model suggested by the International Panel on Climate Change (IPCC) does not provide a means by which customers can compare airline suppliers on environmental

\footnotetext{
* corresponding author: k.mason@ cranfield.ac.uk
} 
performance. This paper aims to demonstrate the potential of a prototype methodology for carbon calculation that enables such assessment and highlight some key environmental performance differences between carriers whereas they would be measured as identical using the DEFRA-type measurement approach.

Some studies suggest that somewhere in the region of $10 \%-20 \%$ of business travel may be in some way escapable by either replacing the travel with alternative forms of communication or by simply stopping unnecessary travel (Coddington, 1993, Feldman, 1993, Arnfalk and Kogg, 2003 and Cairns et al., 2004). If this 20\% saving in business related air travel can be accessed and reductions achieved then this will lead to a significant fall in carbon emissions as airlines alter schedules and networks accordingly. To do this will require both levers / drivers for change in current business travel behaviour and systems to enable change in behaviour.

While for some companies (e.g. manufacturing sector companies), travel may represent only a small part of their carbon footprint, for consultancies, banks, and other service industry companies, travel may account for as much as half of the company's carbon emissions.For example, around $40 \%$ of HSBCs carbon emissions are travel related, and when in 2004 the CEO of the bank announced it would become carbon neutral, the travel manager's role expanded to work out ways to reduce the bank's travel related carbon footprint (BBC News, 2004).

\section{A prototype for an advanced carbon calculation methodology for air travel}

One of the key limitations to airline carbon calculators currently in the market is they rarely distinguish between individual airline performances. By demonstrating it is possible to develop a system to distinguish between airlines on environmental performance, companies may be able to select preferred airline suppliers based on their environmental performance.

\section{Review of existing methodologies for carbon emissions}

The Intergovernmental Panel on Climate Change (1997) provides a two-tired methodology in the "Greenhouse Gas Inventory Reference Manual" as a framework for estimating and reporting the emissions from aviation. The first tier is the simplest methodology, based only an aggregate number for fuel consumption to be multiplied with average emission factors. The second "Tier 2" methodology estimates emissions in two flying phases; the Landing and Take Off (LTO), and cruise phases. Fuel burn is higher in the LTO phase than cruise phase as the aircraft engines are working harder. As the aircraft reaches full cruise altitude the engines can work less hard and also less fuel is burnt at higher altitudes due to the thinner atmosphere. In the "Tier 2" approach, emissions for these two phases are calculated separately and are then aggregated. 
Emissions for a flight depends on the type of aircraft, type of engines, altitude and distance flown. DEFRA studied average emission level of air transport and presented emission factors for domestic and international flights on several routes using default average factors for $\mathrm{CO}_{2}$ emissions and average flight distances and load factors (see Table 1).

\section{TABLE 1 ABOUT HERE}

In a similar study, Table 2 shows examples of emission levels for three flights and the assumptions used by CE Delft (2005 and 2007). CE Delft used fuel consumption data taken from the CORINAIR Emission Inventory Guidebook (as did DEFRA). Comparing the two tables, differences can be attributed to aircraft selection, stage length and load factors. Other results of carbon emissions levels estimated in a number of other are described in Table 3.

TABLE 2 ABOUT HERE

TABLE 3 ABOUT HERE

The results of the studies which assessed the emissions levels are calculated mainly based on three categorised markets; short haul, medium range and long haul routes, using assumptions and average or aggregated data (Intergovernmental Panel on Climate Change, 1998; Jardine, 2005; CE Delft, 2005 and 2007; Department for Environment, Food and Rural Affairs, 2005 and 2007). These factors are, in practice, very different between airlines and routes (Faber et al, 2007) according to the fuel efficiency of the aircraft used and operational performances. The review highlighted the following:

1. There is little measure consistency between the carbon calculators currently available- i.e. the same journey would be measured at different levels of carbon emissions by different calculators

2. Different calculators adopt different methodologies

3. Most available calculators do not allow travel managers to evaluate supplier environmental performance as most calculators tend to treat all airlines as having the same performance for similar routes.

4. Many carbon calculators provided by suppliers (such as airlines) estimate the carbon emissions level by the number of passengers on the sector based on the desired load factors (such as $88 \%$ as used by one airline) or assuming $100 \%$ load factors and using very high efficient fuel consumption factors. 


\section{A Methodology for an Advanced Carbon Calculator}

To develop a calculator that more accurately reflects actual air transport activity, a disaggregated (bottom-up) approach was adopted. It aims to demonstrate current emissions levels in the air transport market by estimating and analysing the carbon emissions by route, stage length, aircraft type used, number of seats supplied on each aircraft and the distance flown on each route. Fundamentally, this approach follows the acknowledged methodologies based on revised 1996 IPCC "Guidelines for National Greenhouse Gas Inventories: Reference Manual and Emission Inventories" (EEA, 2006) for estimating emissions.

\section{FIGURE 1 ABOUT HERE}

Aircraft type, cruise altitude and sector distance are used to calculate the fuel comsumption and therefore emissions during the LTO cycle and cruising stage on each route. An aircraft's fuel burn on a route is not linear with distance and an aircraft burns a relatively large amount of fuel in the initial climb and a lower account of fuel while flying typical descent schedules. Emissions during the LTO cycle, by aircraft type, are obtained from the IPCC guidelines (1997) and the Emission Inventory Guidebook (EEA, 2006). Subsequently fuel consumptions during cruise stage are calculated using performance tables from Base of Aircraft Data (BADA) Revision 3.4 and 3.6 ${ }^{1}$. These calculations are also based on the most frequently used cruise altitude for each route. On shorter sectors lower cruise altitudes are generally used and here the fuel efficiency of the aircraft is less than if a higher altitude is used. To allow for the climb from leaving exiting the Take-off phase (at 3,000ft) to the operated cruise altitude (perhaps 30,000ft), the model adds $10-15$ mins to the cruise time depending on the length of the sector and ultimate cruise altitude.

Traffic data for 2006 (1,626 routes and 59 aircraft types) on the UK domestic routes and the intra-EU routes serving UK airports was obtained by the UK Civil Aviation Authority.The great circle distance is used for sector distances following NASA's methodology (1994), however such an approach does not allow for air traffic management inefficiencies which can add between around $10 \%$ to flight times due to circuitous routings and / or local traffic delays leading to time spent in holding patterns. Such inefficiencies are recognised but were considered mainly beyond the control of the airlines $^{2}$ and therefore beyond the scope of this research. For the North Atlantic study, a

\footnotetext{
${ }^{1}$ It was issued in September 2004 European Organisation for the safety of air navigation (BADA 3.6 Performance Summary Tables). The BADA database do not include many smaller aircraft type and therefore to miniise the use of "average" or "exemplar" aircraft in place of real aircraft, EEA data were used for the aircraft missing from the BADA dataset.

2 Although the authors recognise that some indirect flight paths are adopted by airlines to attract lower en-route air traffic charges.
} 
slightly different methodology was undertaken and Association of European Airlines (AEA) data for 2004 was used.

\section{Emissions by aircraft type}

Figure 2 shows emission levels, across a range of sector lengths for different aircraft. These are calculated based on the assumptions of typical seat configurations (the number of seats supplied) and $75 \%$ load factor. In practice, the results of these calculations will vary based on the actual number of seat configured in an aircraft and actual load factors airlines achieved.

The figure shows that carbon emissions per passenger kilometre is high on short sectors, as the fuel burn during the LTO cycle becomes a relatively more significant part of the fuel burn of the entire flight. For larger aircraft on medium and long-haul flights, the LTO cycle is less significant, because the cruising stage forms the major part of fuel burn. Note there is a slight decrease in flight efficiency with increased distance, due to the greater fuel load that must be carried. The figure highlights the differences between two-engined aircraft and four-engined aircraft like B-777 and B-747. Newly developed aircraft such as B-737-700 and B-777, produce lower emissions than older generation aircraft type.

FIGURE 2 ABOUT HERE

\section{The UK Domestic market}

Figure 3 contrasts the $\mathrm{CO}_{2}$ emissions differences between airlines, and compares carbon emissions $(\mathrm{g}) / \mathrm{pkm}$ by airline in the UK domestic market. While, turboprop aircraft generally have lower emissions per flight than jet aircraft, the emissions levels (on a per passenger kilometre basis: $\mathrm{g} / \mathrm{pkm}$ ) of airlines, which are operating aircraft such as ATR 42 and BAE 146, are relatively high while those of airlines, which are operating B737 series and A320 families, are relatively low. This is, in part, because the average load factors of the latter airlines are comparatively higher and are operate on relatively longer domestic sectors $(450-550 \mathrm{kms})$.

FIGURE 3 ABOUT HERE 
When total emissions by airline correlates to the scale of airline's business in the UK domestic market. In particular, the top two airlines produce over $42 \%$ of the emissions in 2006 and $94 \%$ was shared out by the top 12 airlines in the UK domestic market (see Figure 4).

\section{FIGURE 4 ABOUT HERE}

More than half of emissions for domestic UK air services are created on routes from / to London with the trunk routes to Glasgow and Edinburgh the largest two routes.

\section{FIGURE 5 ABOUT HERE}

Figure 6 depicts the top 20 routes in terms of seats supplied and the annual carbon emissions (in 2006). Load factors achieved vary dramatically from $57 \%$ to $81 \%$, and this has a significant impact on the emissions per seat with higher load factors reducing the emissions per passenger carried as can be seen in Figure 7.

FIGURE 6 ABOUT HERE 
The average distance flown of the top 20 routes is $581 \mathrm{kms}$ with $78 \%$ average load factor and an average of $162 \mathrm{~g}$ carbon emissions per passenger kilometre. On the routes operated by low cost carriers such as Edinburgh-London Gatwick and the Glasgow Prestwick-London Stansted, the per passenger carbon emissions are relatively low due to high seat density and high load factors achieved compared to the routes, where network carriers predominate. The impact of low cost carriers in the EU short haul market has been remarkable, drawing considerable market share from incumbent network and regional carriers. The passenger numbers have also risen dramatically. Low cost carriers tend to operate new fuel-efficient aircraft, have high seating density and report exceedingly high load factors. Together this means passengers on low cost carriers tend to have relatively low carbon emissions on a grams per passenger kilometre basis compared with passengers on network or regional carriers. However, if a significant proportion of their passengers have been stimulated to travel by their low fares then their environmental impact of these carriers could be considered to be damaging. This LCC environmental paradox depends on whether passengers using their services are newly generated or traffic stimulated by low fares. The European Low Fares Airlines Association (2004) indicated that $60 \%$ of their members traffic was generated by low fares, however the UK Civil Aviation Authority (2006) found the reverse suggesting that the low cost carriers had taken market share from other carriers but the growth in the market did not include newly generated traffic once natural growth in the market has been included.

\section{FIGURE 7 ABOUT HERE}

\section{Intra-EU serving $U K$ airports routes}

In this section, the intra-EU routes serving UK (excluding the UK domestic market) are analysed using UK CAA data for 2006. This market covers the sector lengths varying widely from the short haul sectors like the Jersey-Cherbourg route $(79 \mathrm{kms})$ to medium haul sectors as the London Heathrow-Larnaka in Cyprus $(3,600 \mathrm{kms})$ Figure $8^{3}$ shows the average carbon emissions per sector on the intra-EU routes in 2006.

\section{FIGURE 8 ABOUT HERE}

The emissions levels per sector can be segmented into groups based on the type of airline operations: network carriers from outside EU and EEA countries, charter airlines, network carriers in EU, low cost carriers and regional airlines. Figure 8 demonstrates that the long-range sectors produce more emissions per flight rather than short sectors and illustrates the differences between airlines and aircraft type they used.

\footnotetext{
3 The allocation of emissions to cargo carried has been excluded in this analysis. However, further development of the prototype carbon calculator should be extended to include it.
} 
Network carriers from outside EU and EEA countries operate aircraft type for the long range flights on this market as part of the international fifth freedom operation, e.g. London Heathrow-Paris Charles de Gaulle by Air China or American Airlines. On these sectors the carbon emissions $(\mathrm{g}) / \mathrm{pkm}$ are very high as a result of very low load factors on the relatively large aircraft. When looking at the same figures on a per passenger kilometre basis (Figure 9), the airlines plotted above the logarithmic line-of-best-fit are mainly network carriers from outside the EU, while other airlines plotted below the line are mainly charter airlines, network carriers in EU, low cost carries and regional airlines. The figure suggests that the airlines that have the highest per passenger carbon footprint are non-EU carriers operating routes under fifth freedom traffic rights.

FIGURE 9 ABOUT HERE 
The differences of carbon emissions levels between airlines can in part to be understood clearly by comparing carbon emissions levels per passenger per sector incorporating load factors by airline. Average load factors of LCCs like Ryanair (78\%) and easyJet $(81 \%)$ and charter airlines such as Monarch Airlines (75\%) and GB Airways (83\%) are comparatively high compared to those of e.g. CSA Czech Airlines (56\%), Croatia Airlines (63\%), Bulgaria Air (65\%), and regional airlines as Flybe (65\%), BA Connect $(59 \%)$ and Luxair (54\%).

When carbon emissions levels are expressed per passenger kilometre flown, the differences between airlines are highlighted further. The carbon emissions (g)/pkm of airlines which operate on short sectors with low load factor become higher (see Figure $10)$.

\section{FIGURE 10 ABOUT HERE}

On the other hand, the emissions produced by the three key players in this market are so significant that the effects of their business practices on the market are important (see Figure 11).

\section{FIGURE 11 ABOUT HERE}

The intra-EU serving UK routes can be segmented into four groups according to the levels of carbon emissions ( $\mathrm{g}$ ) per passenger kilometre (see Table 4).

\section{TABLE 4 ABOUT HERE}

Group A represents airlines operating on routes where average carbon emissions $(\mathrm{g}) / \mathrm{pkm}$ is less than $100 \mathrm{~g} / \mathrm{pkm}$, and Group B is where this figure is less than $150 \mathrm{~g} / \mathrm{pkm}$. Groups A and B form the majority of the intra-EU serving UK routes, accounting for more than $71 \%$ of the number of passengers carried and $59 \%$ of the number of departures. The routes, of which average carbon emissions $(\mathrm{g}) / \mathrm{pkm}$ are between 150 and 250, belong to Group C, while Group D consists of the routes, which produce carbon emissions over $250 \mathrm{~g} / \mathrm{pkm}$. Table 5 highlights the differences among these route groups by carbon emissions $(\mathrm{g}) / \mathrm{pkm}$, average distance flown and load factors of each route group.

\section{TABLE 5 ABOUT HERE}

The very low emissions market, Group A (with average carbon emissions: $87 \mathrm{~g} / \mathrm{pkm}$ ) accounts for $31 \%$ of demand and contribute only $23 \%$ of emission. Group B (with average carbon emissions of $123 \mathrm{~g} / \mathrm{pkm}$ ) has $40 \%$ of demand and $42 \%$ of emissions. Group $\mathrm{C}$ routes are largely operated by network carriers for their hub and spoke network 
routes accounting for $23 \%$ of the passengers, but $29 \%$ of the emissions. The high emissions Group D is mainly operated by regional carriers and although is only a small group carrying just $4 \%$ of traffic it accounts for $6 \%$ of emissions. The gaps between passengers carried and emissions contributions can be attributed mainly to aircraft used, stage length, load factors achieved, and cabin seating configuration. While the analysis here has segmented all the operators on routes by their average passenger carbon emissions, it would also be worthwhile to undertake an analysis of emissions levels by different airline business models (e.g. full service network, low cost, regional, charter, etc.) This paper establishes an appropriate methodology to appraise the carbon footprints of differing business models and is currently being used to undertake this further work being conducted for an Omega funded study to be available in 2009.

\section{North Atlantic Analysis}

Long distance international routes are analysed here by using the North Atlantic market as an example. Traffic data by airline, route and real load factors in both premium and economy cabins, published by Association of European Airlines (AEA) in 2004 are used to estimate the number of carbon emissions by for each airline. Compared to previous sections, a different calculation methodology was adopted for this market because of individual route data limitations.

Where airlines operate multiple cabins, as is the usual case in long haul flying, the carbon emission estimates should reflect these different products. Carbon emission levels by class may be analysed by considering the seat space which each passenger occupies, taking into to account the proportion of number of passengers in each class compared to the number of passengers on the sector flight. Therefore, if a passenger in First Class occupies twice as much space as a passenger in Economy Class, then the First Class passenger's emissions estimate should be twice that of the Economy Class passenger. Spaces of other facilities like galleys, aisles, lavatories, and bar spaces are excluded in this analysis. While this real-estate approach does not directly consider the weight of the passengers (or their luggage), the opportunity cost of carrying more economy passengers instead of fewer business class passengers is considered to be an appropriate way to allocate emissions. However two economy passengers (plus baggage) is heavier than one business class passenger. To try to estimate the weight of passengers by cabin for each airline, including the weight of the airline seats (business and first class seats are considerably more heavy than economy seats) that are dependent on a wide range of factors including in-flight entertainment systems, seat manufacturers and materials used, was impossible due to data limitations.

Figure 12 shows the result of the estimated carbon emissions $(\mathrm{g} / \mathrm{pkm}$ : grams per passenger kilometres) by airline on North Atlantic routes in 2004 (average distance flown: 6,825kms), In this analysis emissions are centred between 100 and $150 \mathrm{~g} / \mathrm{pkm}$. Several airlines that use new generation aircraft (B777 and A340) and achieve high load factors (over 88\%) produce less than $100 \mathrm{~g} / \mathrm{pkm}$. On the other hand, the emissions of airlines which operated older generation aircraft (B747-200) with relatively low load factors (less than 75\%) have very high emissions levels with one over $240 \mathrm{~g} / \mathrm{pkm}$. 
These results are estimated based on the average number of passengers carried on the sectors. They are affected by load factors and capacities of each airline and capacities are affected by the existence of first class and the seat pitches of each class. They vary depending on each airline's strategy; the average space occupied by passenger on one network carrier's First Class ( 80 inches) and Business Class seat (61 inches) is 2.3 times longer than that of its Economy Class seat (31 inches) when the differences in load factor by cabin are accounted for. Another carrier's business class seat (60 inches) is 1.9 times longer than that of economy class ( 32 inches).

The number of seats and load factors in the first and business class affect the result of these calculations significantly. Carriers with very large business class cabins will have higher emissions levels per passenger than those that carry a larger number of economy passengers in the same aircraft type.

Figure 13 contrasts the differences of the results between the economy class and first/ business class. For airlines that have both first class and business class, emissions level in those classes may be more than double of those of passengers in economy class. One carrier's emission level for first/business class is estimated at over $400 \mathrm{~g} / \mathrm{pkm}$ because not only was it operating B747-200 on a quarter of its long haul routes but also the number of passengers in both first and business class were very low. The figure also shows estimated emissions level for a business class-only-airlines (airlines " $\mathrm{S}$ " and "T") as 255 to $337 \mathrm{~g} / \mathrm{pkm}$, based on operations in 2007 and 2008 which is higher than average of first/business class $(220 \mathrm{~g} / \mathrm{pkm})$ of other network carriers.

\section{FIGURE 13 ABOUT HERE}

The results clearly demonstrate the differences among airlines, reflecting their strategies. Fuel-efficient new generation aircraft, operating without a first class cabin, and operating at high load factors particularly in the business class are the factors to improve the level of carbon emissions per passenger $\mathrm{kms}$ on the long haul routes. To understand the carbon foot print level on these sectors, it is important to consider these factors.

\section{Conclusions}

The key areas for airlines to concentrate efforts to reduce carbon emissions per passenger kilometre are increasing load factor (particularly in First and Business Class in long haul operations), the operation of a fuel-efficient fleet of aircraft, and higher density cabin configurations.

The prototype developed demonstrates that it is possible to build an advanced carbon calculator that uses actual data by airlines and routes for aircraft operated, cabin configuration used, cruise altitude used, and passenger load factors achieved. 
The availability of carbon emission levels by airline and route is a possibility and corporate travel managers need this information to be able to make informed choices on preferred suppliers. Travellers that are charged with reducing their travel related carbon emissions need carbon emissions data by airline at Point-of-Sale to be able to select the most efficient airline. This demand factor will lead airlines to seek methods to reduce their carbon emissions per passenger.

\section{Acknowledgements:}

This work was funded by Omega (www.omega.mmu.ac.uk) and conducted by Cranfield University in association with the Institute of Travel Management. The authors would also like to thank the anonymous reviewers for their insightful comments and suggestions

\section{References}

Arnfalk, P. and Kogg, B., 2003, Service transformation-managing a shift from business travel to virtual meetings. Journal of Cleaner Production, 11, 859-872.

BBC News,2004, HSBC bank to go carbon neutral. news.bbc.co.uk. $6^{\text {th }}$ Dec 2004.

Civil Aviation Authority. (2006), No-frills carriers: Revolution or Evolution? CAP 770. Civil Aviation Authority. London.

Cairns, S., Sloman, L., Newson, C., Anable, J., Kirkbride, A. and Goodwin, P., July 2004. Smarter Choices - Changing the Way We Travel. Department for Transport, London.

CE Delft, 2005. Giving wings to emission tradimg, Inclusion of aviation under the European emission trading system (ETS): design and impacts. Delft.

CE Delft, 2007. Allowance allocation in the EU ETS: The impact on the profitability of the aviation sector under high levels of auctioning. Delft.

Coddington, P., 1993. The Impact of Videoconferencing on Airline Business Traffic. Journal of Travel Research, 32, 64-66.

Department for Environment, Food and Rural Affairs, 2005. Passenger transport emissions factors, methodology paper DEFRA, London

Department for Environment, Food and Rural Affairs ,2007. Act on CO2 calculator: Public trial version Data, Methodology and assumptions paper, DEFRA, London.

Doganis, R., 2002. Flying off Course: The Economics of International Airlines. Routledge, London.

European Commission, 1998. Transport and CO2. European Commission, Brussels.

European Low Fares Airlines Association, 2004. Liberalisation of European Air Transport: The Benefits of Low Fares Airlines to Consumers, Airports, Regions and the Environment. European Low Fares Airlines Association, Brussels. 
European Environment Agency (EEA), 2006. EMEP/CORINAIR (Core Inventory of Air Emissions in Europe) Emission Inventory Guidebook-2007.

Faber, J., Vreede, G. van de., Lee, D. S., 2007. The impact of the use of different benchmarking methodologies on the initial allocation of emissions trading scheme permits to airlines. Final report to DfT Aviation environmental division and the Environment Agency, CE Delft and Manchester Metropolitan University.

Feldman, J. M.,1993. Bane of business travel?. Air Transport World, 30, 44-50.

Gössling, S., Peeters, P., Ceron, J., Dubois, G., Patterson, T., Richardson, R.B., 2005. The eco-efficiency of tourism. Ecological Economics, 54, 417-434.

Intergovernmental Panel on Climate Change (IPCC), 1998. Aviation and the global atmosphere, a special report of IPCC working groups. Intergovernmental Panel on Climate Change, Montreal.

Intergovernmental Panel on Climate Change, 1997. Revised 1996 IPCC guidelines for national greenhouse gas inventories: reference manual, Montreal.

Jardine, C.N., 2005. Calculating the environmental impact of aviation emissions. Environmental Change Institute, Oxford University Centre for the Environment, Oxford.

Mason, K. J. and Alamdari, F., 2007. EU network carriers, low cost carriers and consumer behaviour: a Delphi study of future trends. Journal of Air Transport Management, 13, $299-310$.

NASA, 1994. Jet aircraft engine exhaust emissions database development-Year 1990 and 2015 scenarios. NASA, Washington.

Peeters, P., Szimba, E., Dujinisveld, M., 2007. Major environmental impacts of European tourist transport. Journal of Transport Geography, 15 83-93.

Ross, D, 2007. GHG emissions resulting from aircraft travel. Carbon Planet, Sydney. 
Table 1 - Department for Environment, Food and Rural Affairs report

\begin{tabular}{|c|c|c|c|c|}
\hline Flight type & gCO2/pkm & Calculation Assumptions & $\begin{array}{l}\text { Average } \\
\text { journey } \\
\text { distance for } \\
\text { calculator }\end{array}$ & $\begin{array}{l}\text { Example } \\
\text { journey }\end{array}$ \\
\hline Domestic & 158.0 & $\begin{array}{l}78 \text { seats on the Dash-8 Q400 } \\
139 \text { seats on the B737-400 }\end{array}$ & $463 \mathrm{~km}$ & London-Scotland \\
\hline $\begin{array}{l}\text { Short haul } \\
\text { international }\end{array}$ & 130.4 & $\begin{array}{c}65 \% \text { load factor } \\
1 \\
139 \text { seats }\end{array}$ & $1,108 \mathrm{~km}$ & $\begin{array}{c}\text { UK-Central } \\
\text { Europe }\end{array}$ \\
\hline Long haul & 105.6 & $\begin{array}{c}79.7 \% \text { load factor } \\
346 \text { seats on the B747-400 } \\
261 \text { seats on the B767-300ER }\end{array}$ & $6.482 \mathrm{~km}$ & $\begin{array}{l}\text { UK-East Coast } \\
\text { USA }\end{array}$ \\
\hline
\end{tabular}

Source: Department for Environment Food and Rural Affairs, 2007.

Table 2 - The results of the study by CE Delft

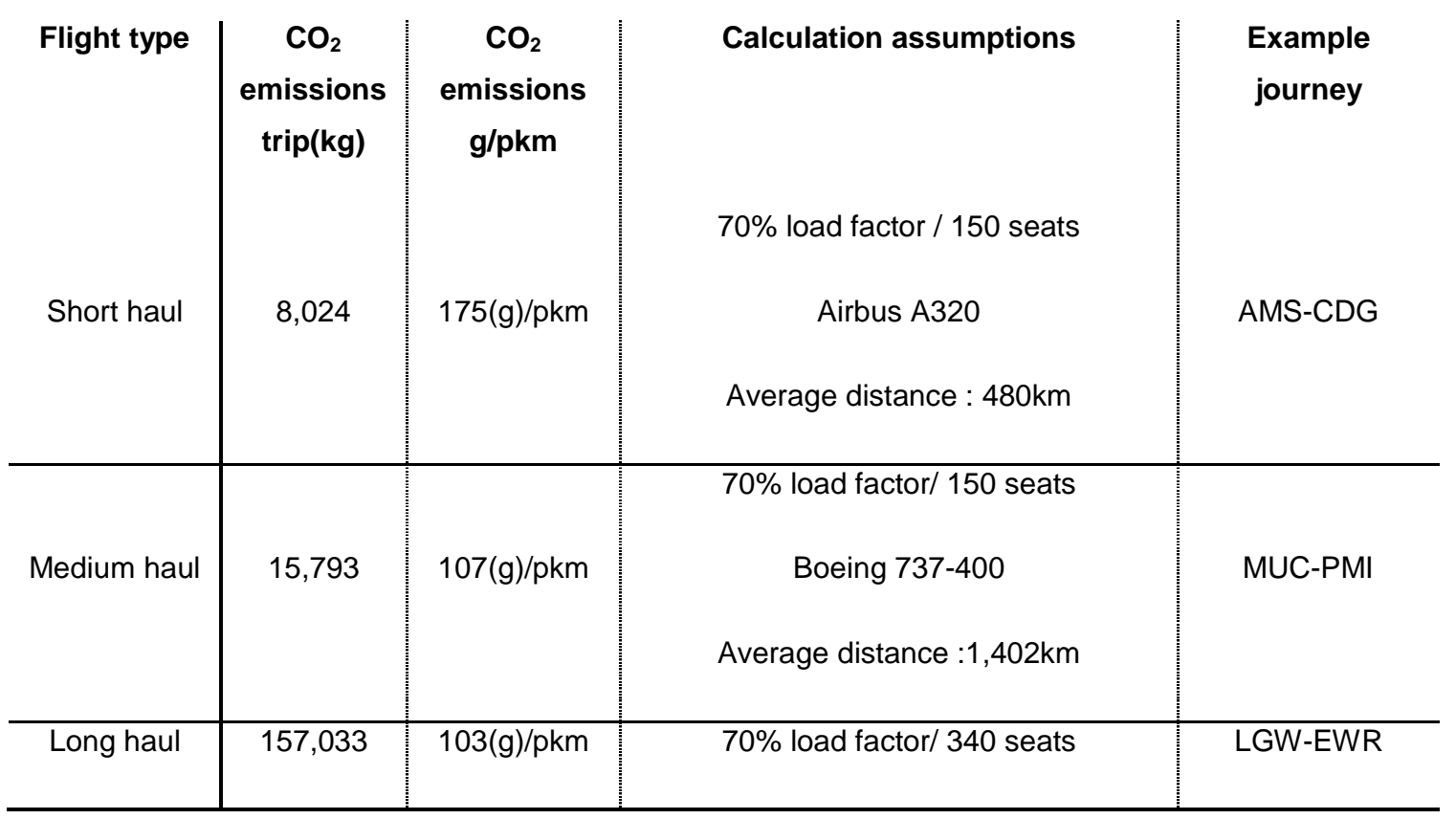




\begin{tabular}{l|l|l} 
& Boeing 777 & \\
Average distance $: 6,404 \mathrm{~km}$ & \\
\hline
\end{tabular}


Table 3 - Carbon emissions levels estimated in various studies

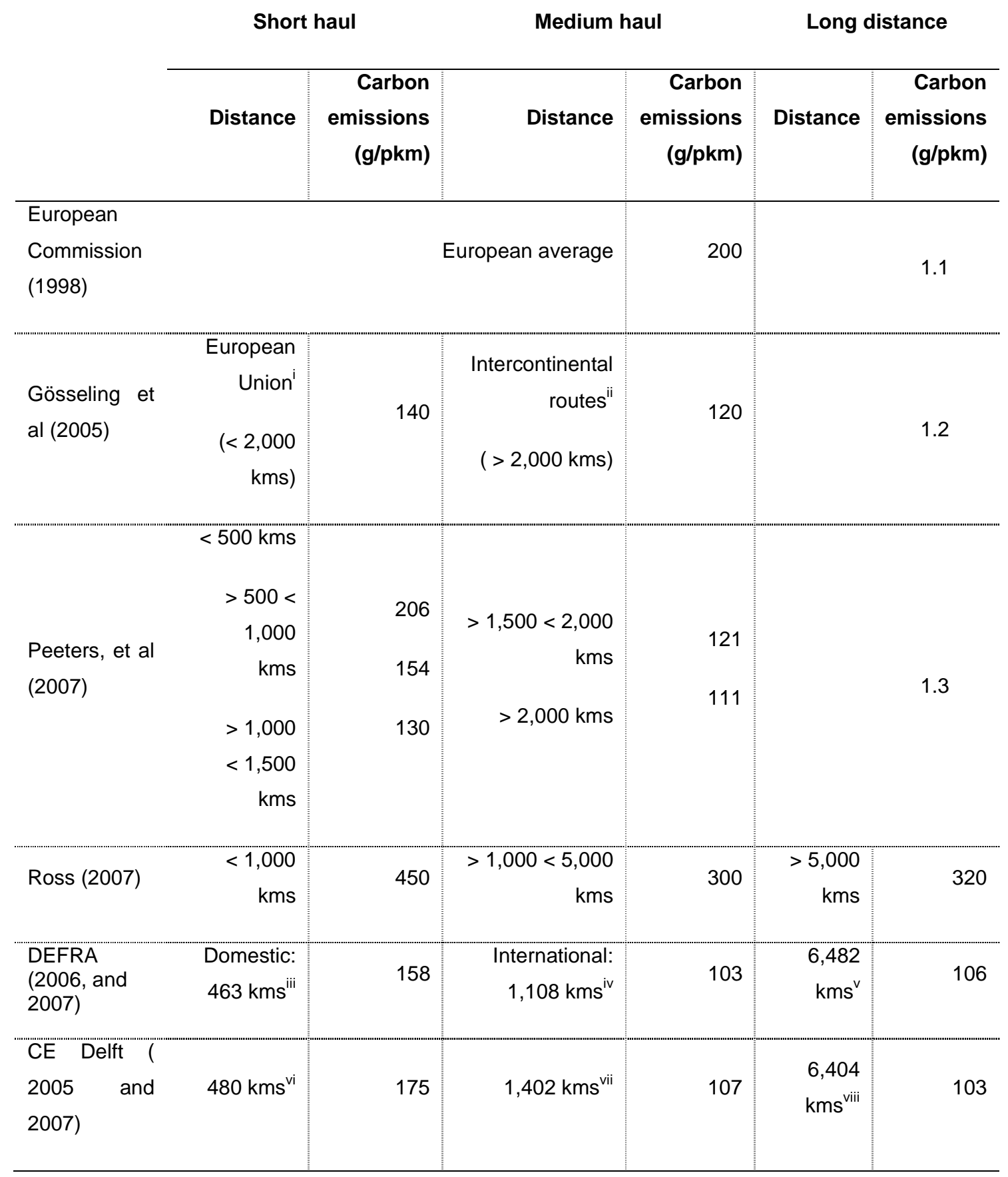


Figure 1 - More refined carbon calculation methodolgy

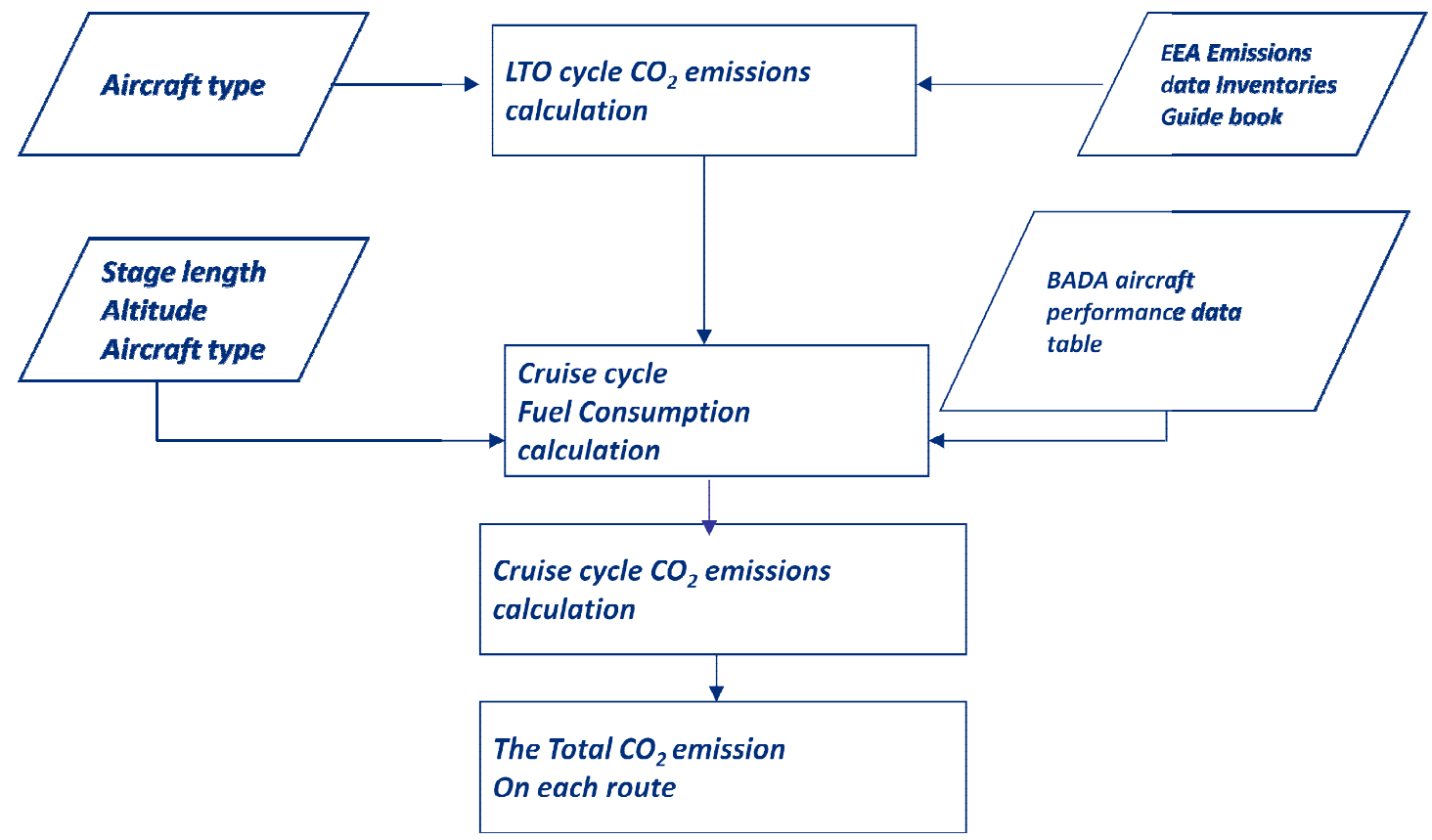

Figure 2 - Carbon emissions $\mathrm{g} / \mathrm{pkm}$ for various aircraft

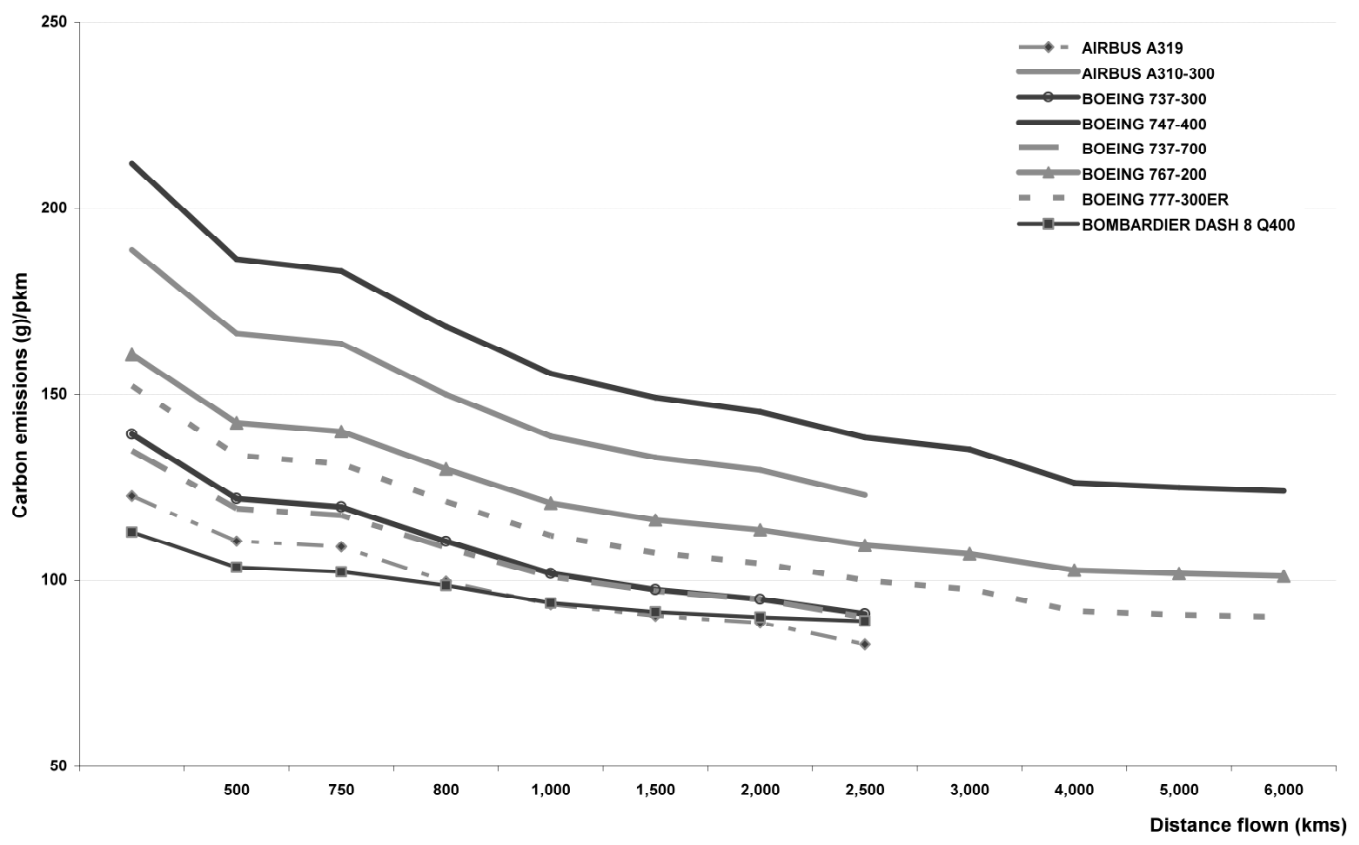


Figure 3 - Average carbon emissions (g)/pkm by airline on UK domestic routes (2006)

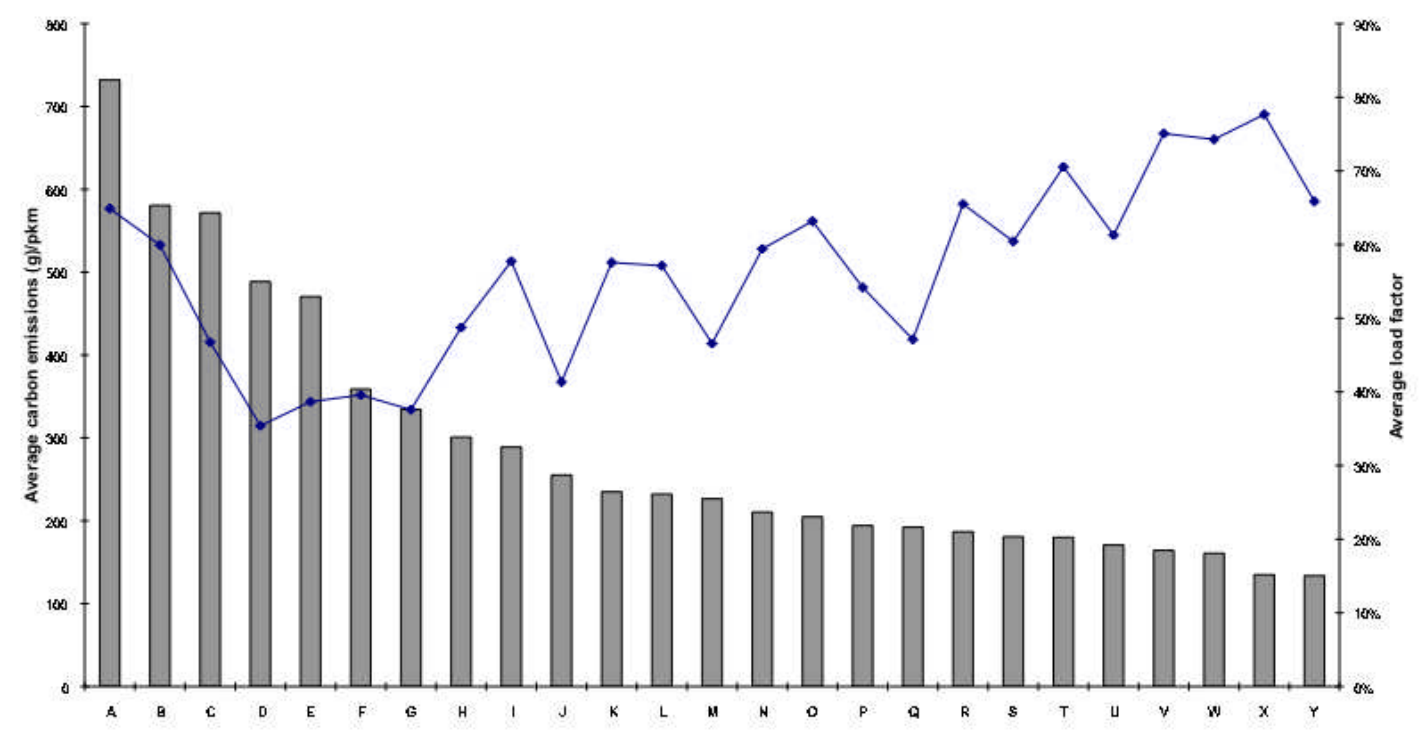

Figure 4 - Carbon emissions (t) by airline on the UK domestic routes (2006)

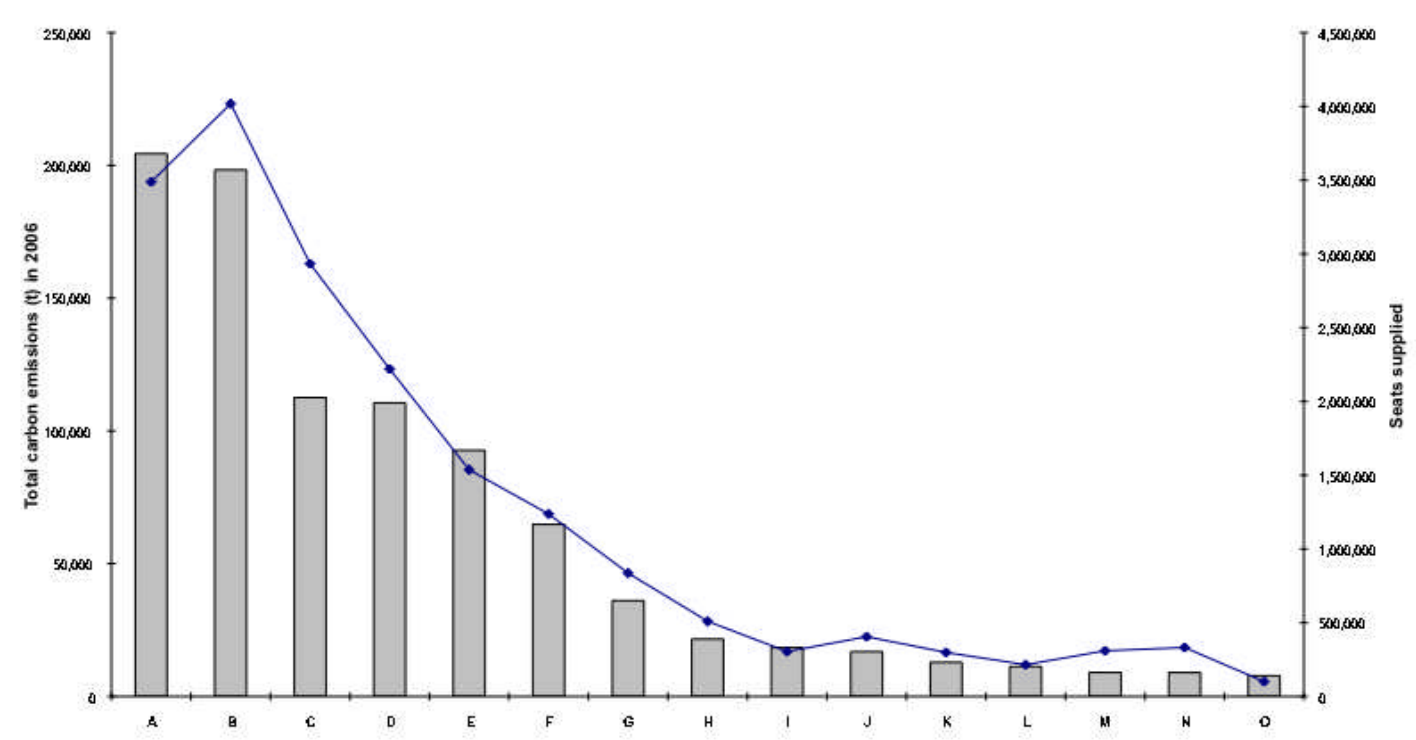


Figure 5 - Carbon emissions ( $t$ ) by route in the UK domestic market (2006)

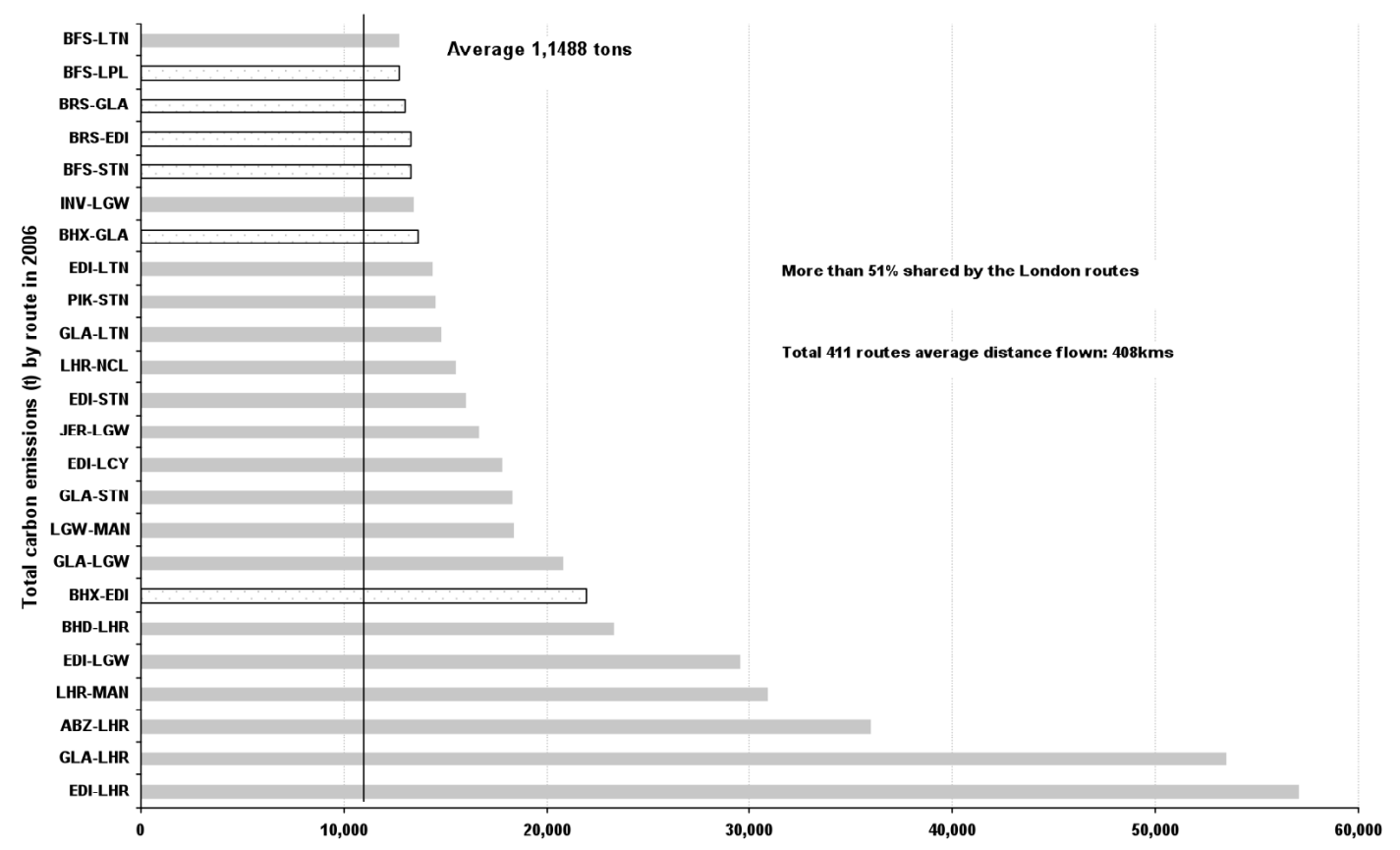

Figure 6 - Top 20 routes of seats supplied and annual carbon emissions (2006)

Figure 7 - Average carbon emissions and load factor by route in the UK domestic market (2006) 


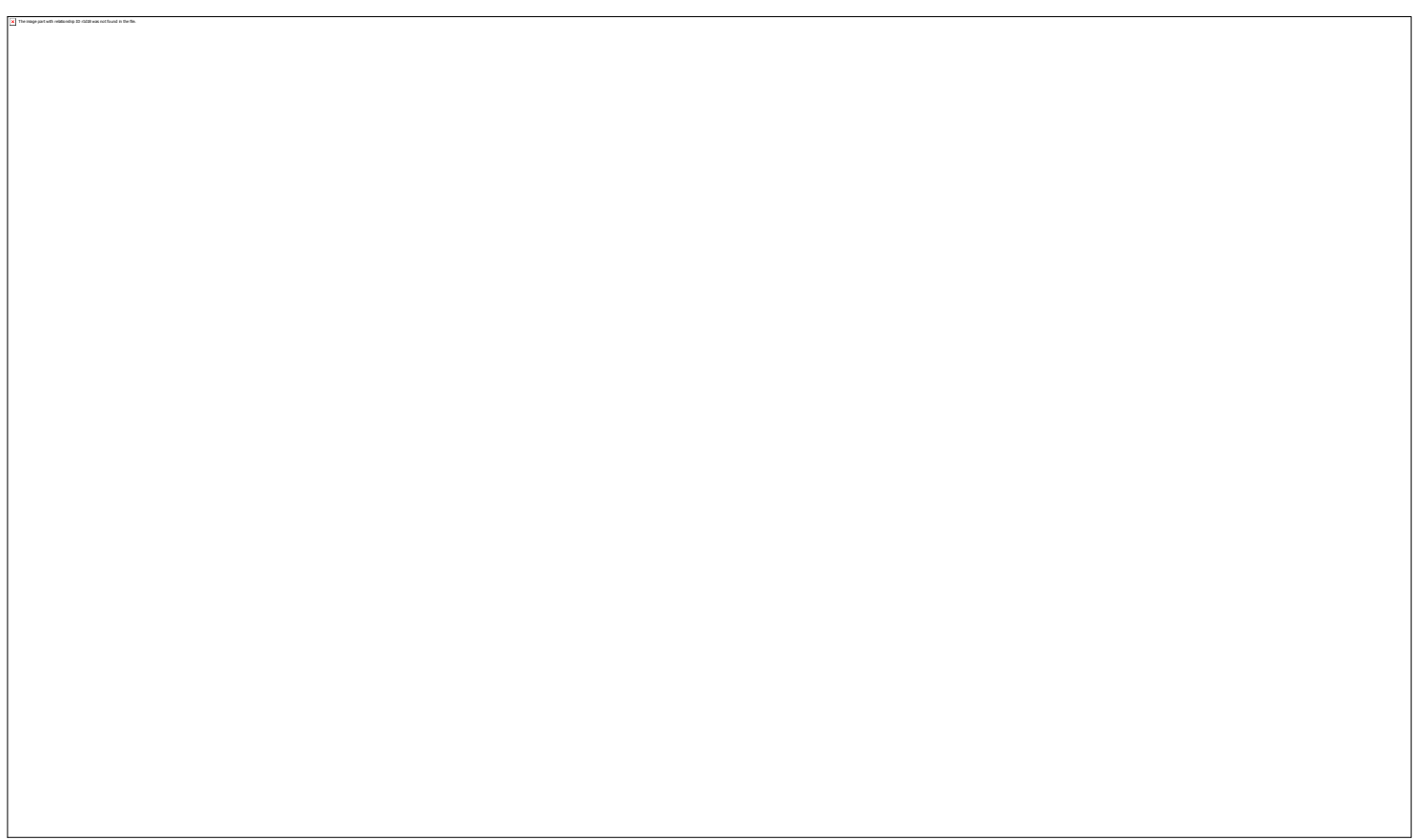


Figure 8 - Average carbon emissions per sector on the intra-EU serving UK (2006)

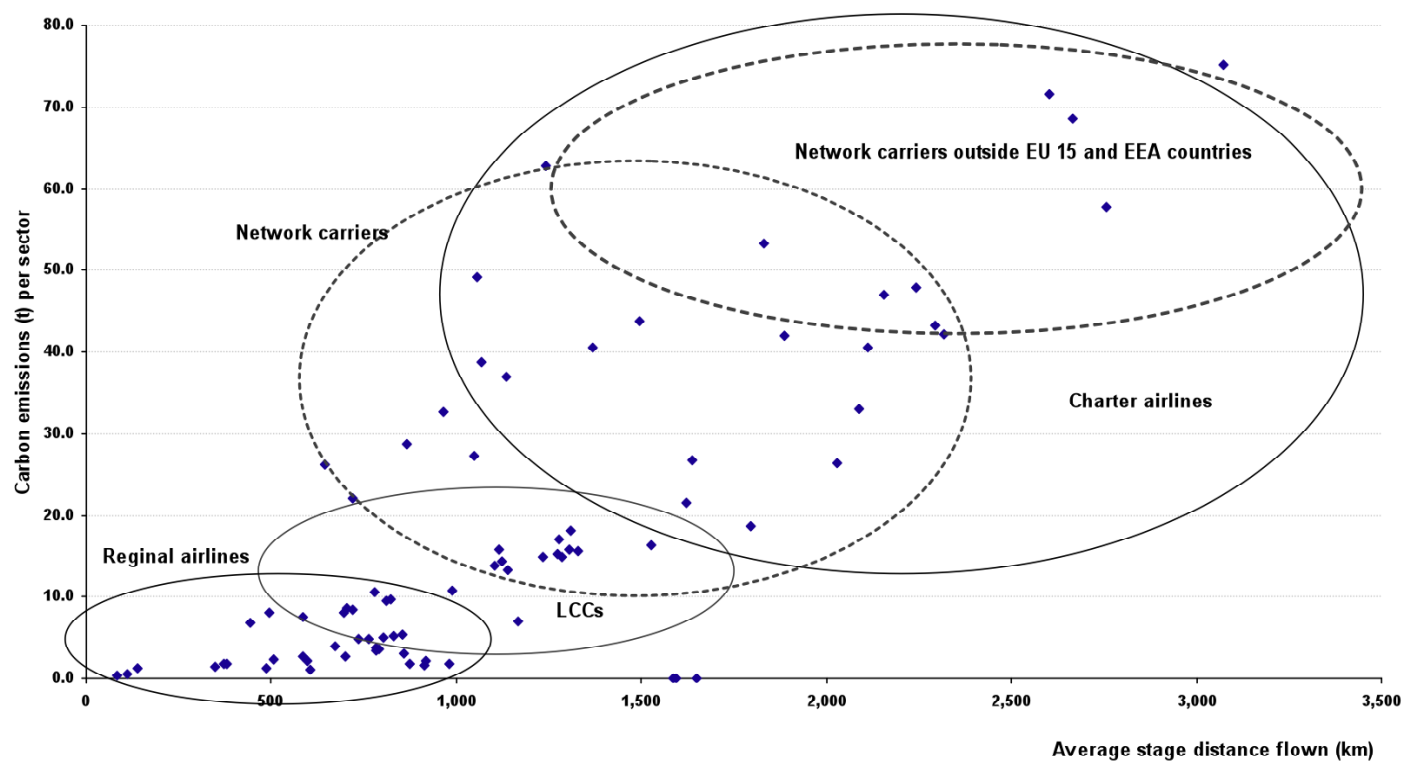

Figure 9 - Carbon emissions (kg) per passengers on a sector vs distance flown (kms)

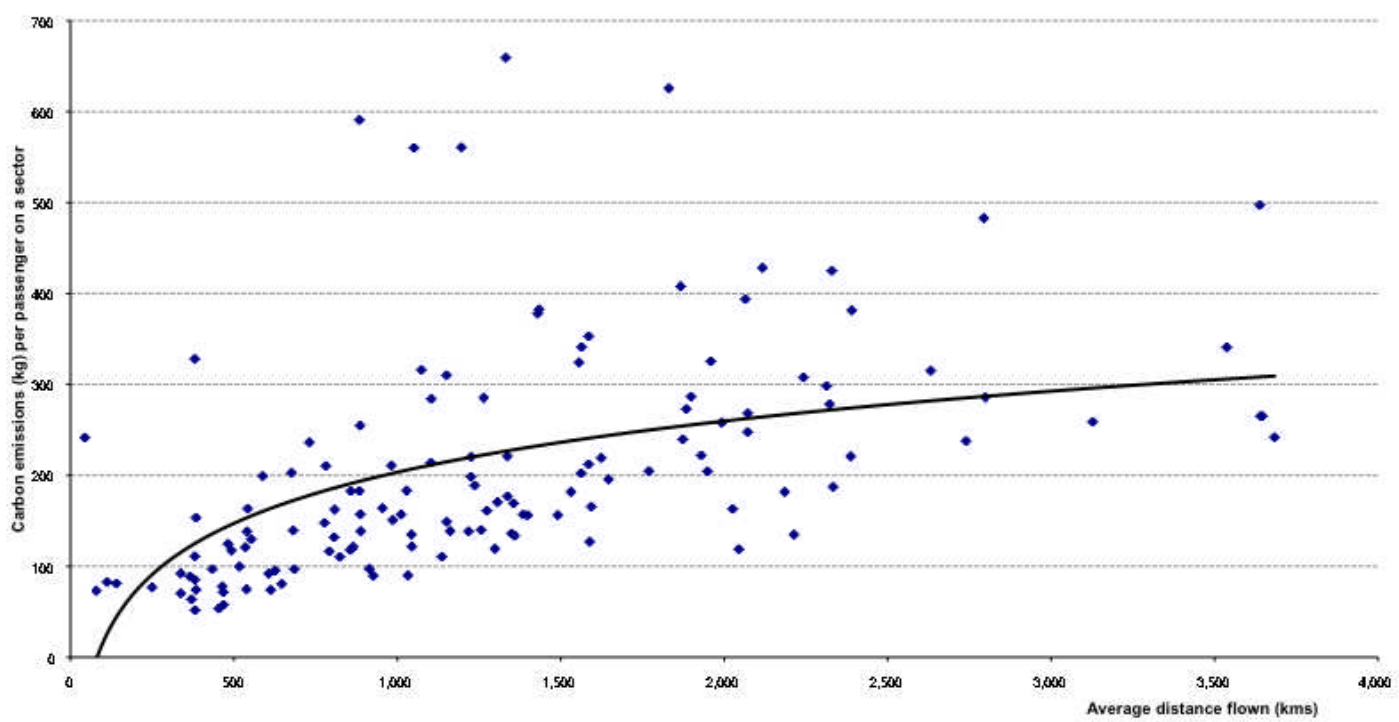


Figure 10 - Carbon emissions (g)/pkm by airline on the intra-EU routes serving UK

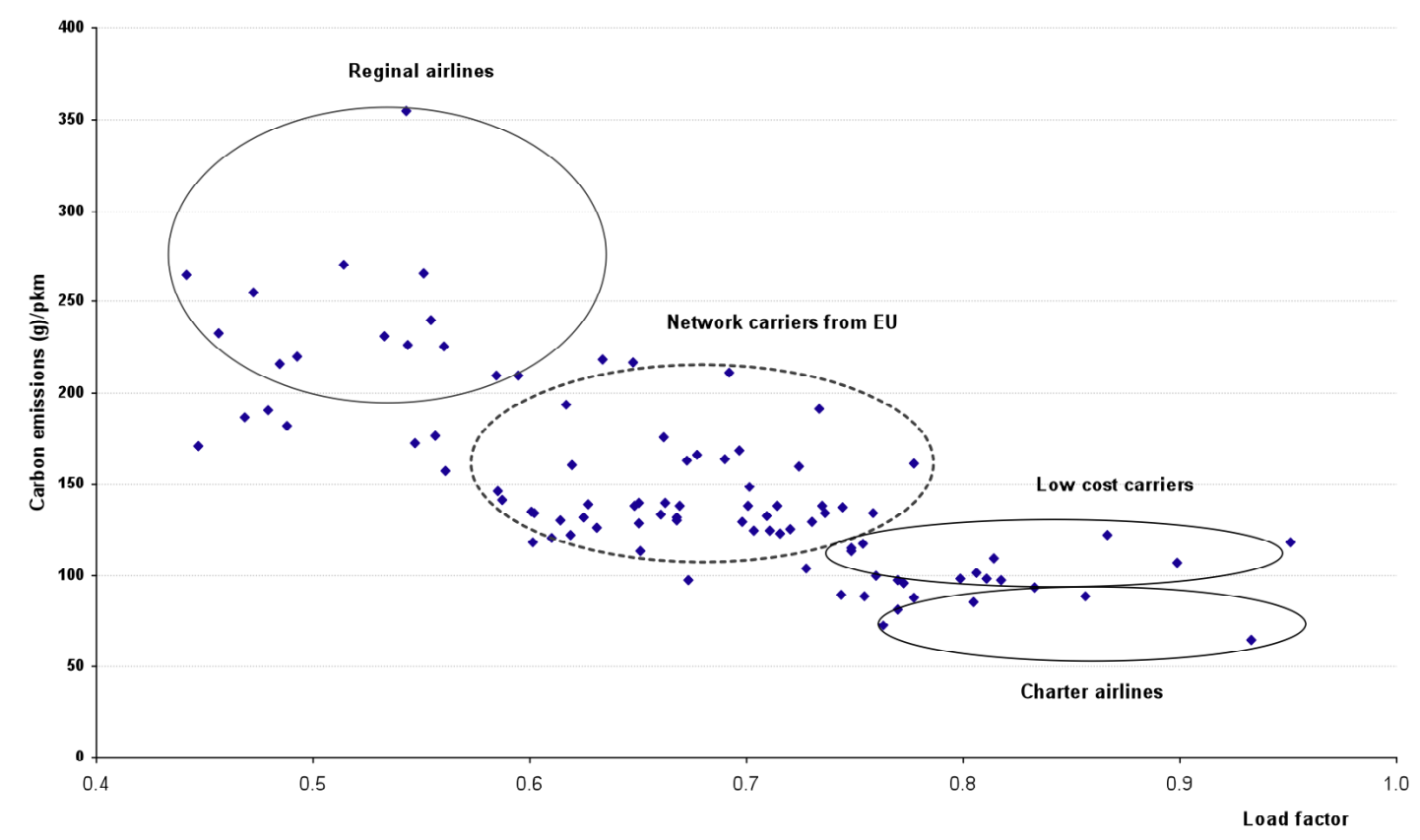

Figure 11 - Carbon emissions ( $t$ ) by airline on the intra-EU routes serving UK (2006)

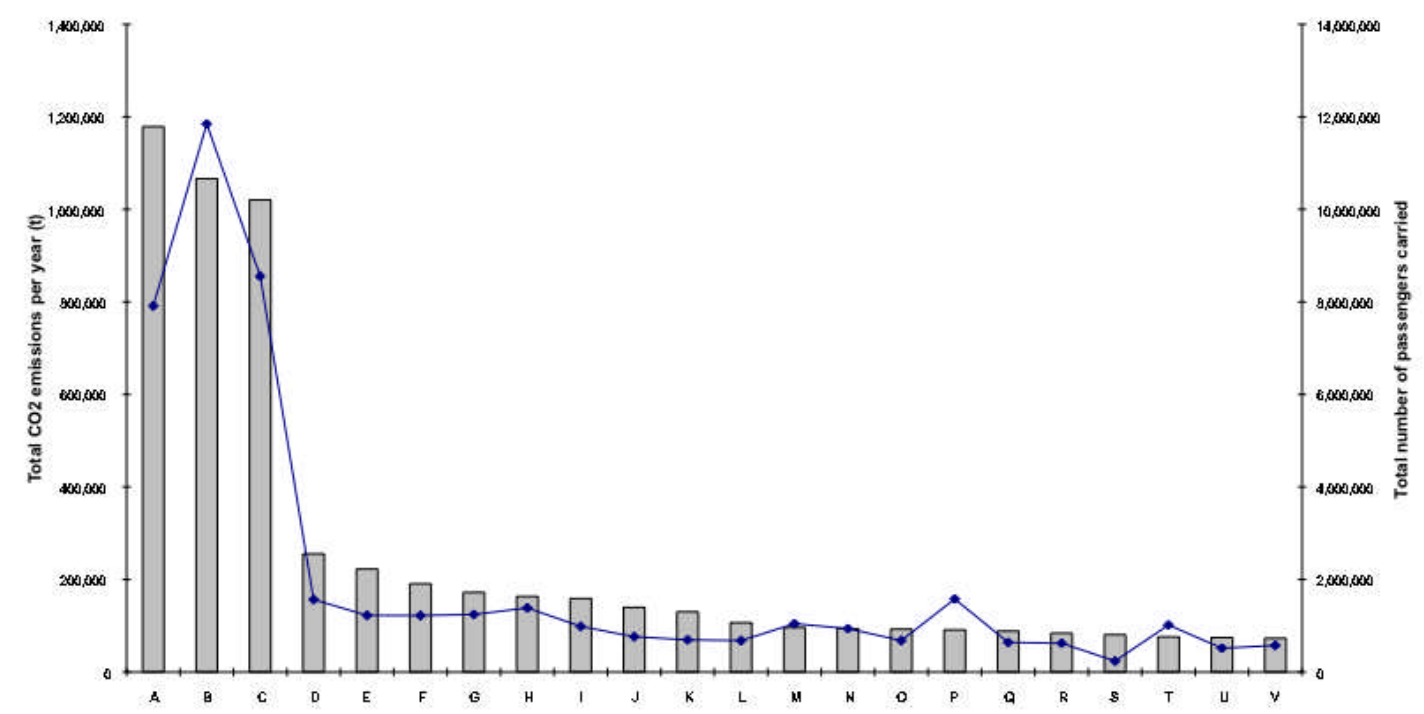

$\mathrm{nb}$ : The individual airlines have been disguised on the request of the funding organisation. 
Table 4 - Route groups by carbon emissions levels (g)/pkm

\begin{tabular}{|c|c|c|c|}
\hline Group & $\begin{array}{c}\text { Weighted average } \\
\text { carbon emissions } \\
(\mathbf{g} / \mathbf{p k m})\end{array}$ & $\begin{array}{c}\text { Share (\%) of passengers } \\
\text { carried }\end{array}$ & Sumber of departures \\
\hline A & $<100$ & $31 \%$ & $22 \%$ \\
\hline B & $<150$ & $40 \%$ & $37 \%$ \\
\hline C & $<250$ & $23 \%$ & $30 \%$ \\
\hline D & $>250$ & $4 \%$ & $7 \%$ \\
\hline
\end{tabular}

Table 5 - Average carbon emissions (g)/pkms on the route of each route group

\begin{tabular}{|c|c|c|c|c|c|c|c|c|}
\hline $\begin{array}{c}\text { Av. } \\
\text { carbon } \\
\text { emission } \\
\text { s (g/pkm) }\end{array}$ & $\begin{array}{c}2 \\
2 \\
3 \\
\text { Main players in } \\
\text { group }\end{array}$ & $\begin{array}{c}\text { Share }(\%) \\
\text { passengers } \\
\text { carried }\end{array}$ & $\begin{array}{l}\text { Share (\%) } \\
\text { emissions }\end{array}$ & 3.1.1 & $\begin{array}{c}\text { A } \\
\text { v. } \\
\text { ca } \\
\text { rb } \\
\text { on } \\
\text { e } \\
\text { mi } \\
\text { ss } \\
\text { io } \\
\text { ns } \\
\text { wi } \\
\text { thi } \\
\mathrm{n} \\
\text { gr } \\
\text { ou } \\
\mathrm{p}\end{array}$ & 3.1 .2 & $\begin{array}{l}\mathrm{c} \\
\mathrm{e}\end{array}$ & 3.1 .3 \\
\hline
\end{tabular}




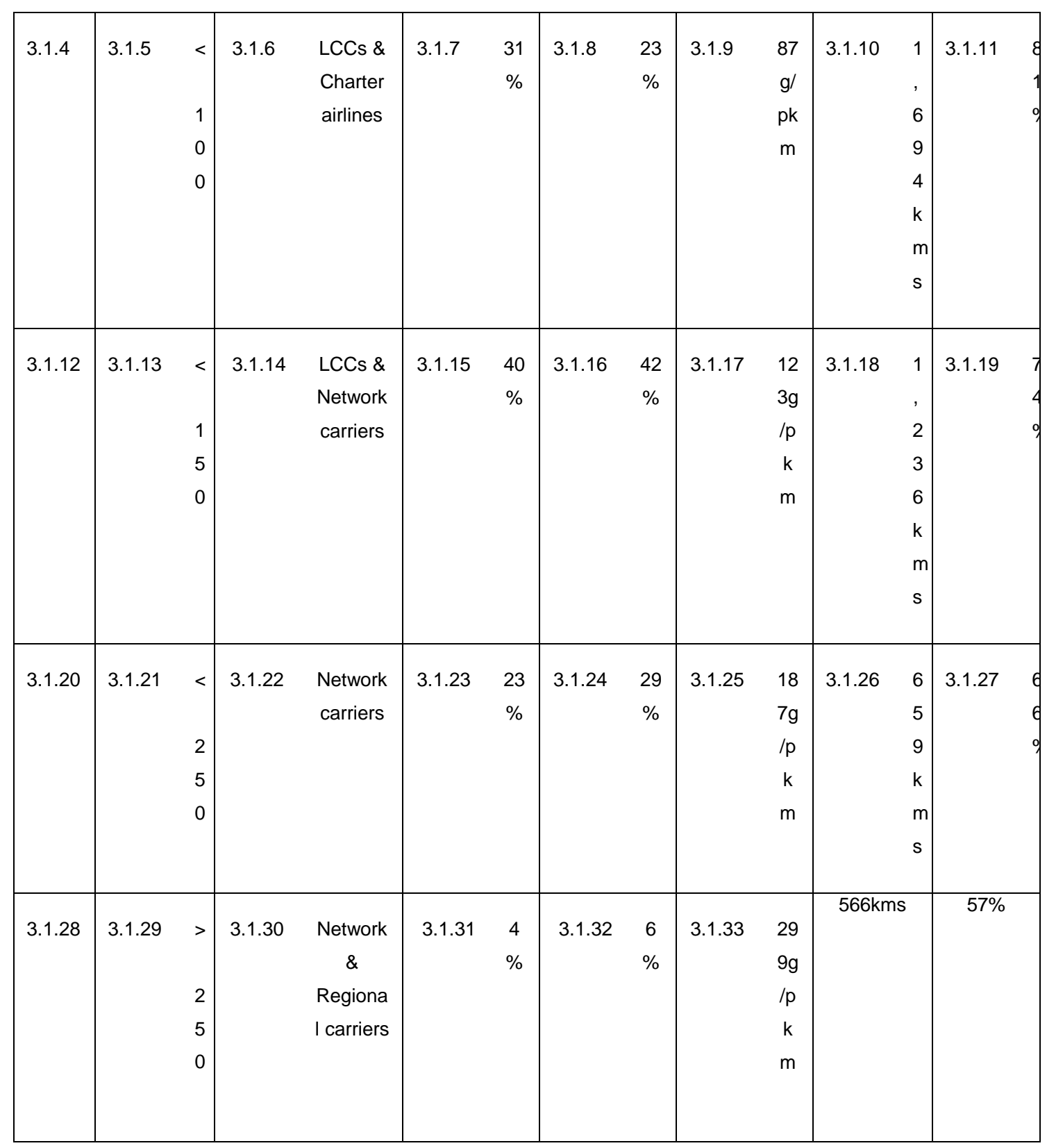


Figure 12 - Average carbon emissions (g)/pkm on the North Atlantic routes in 2004

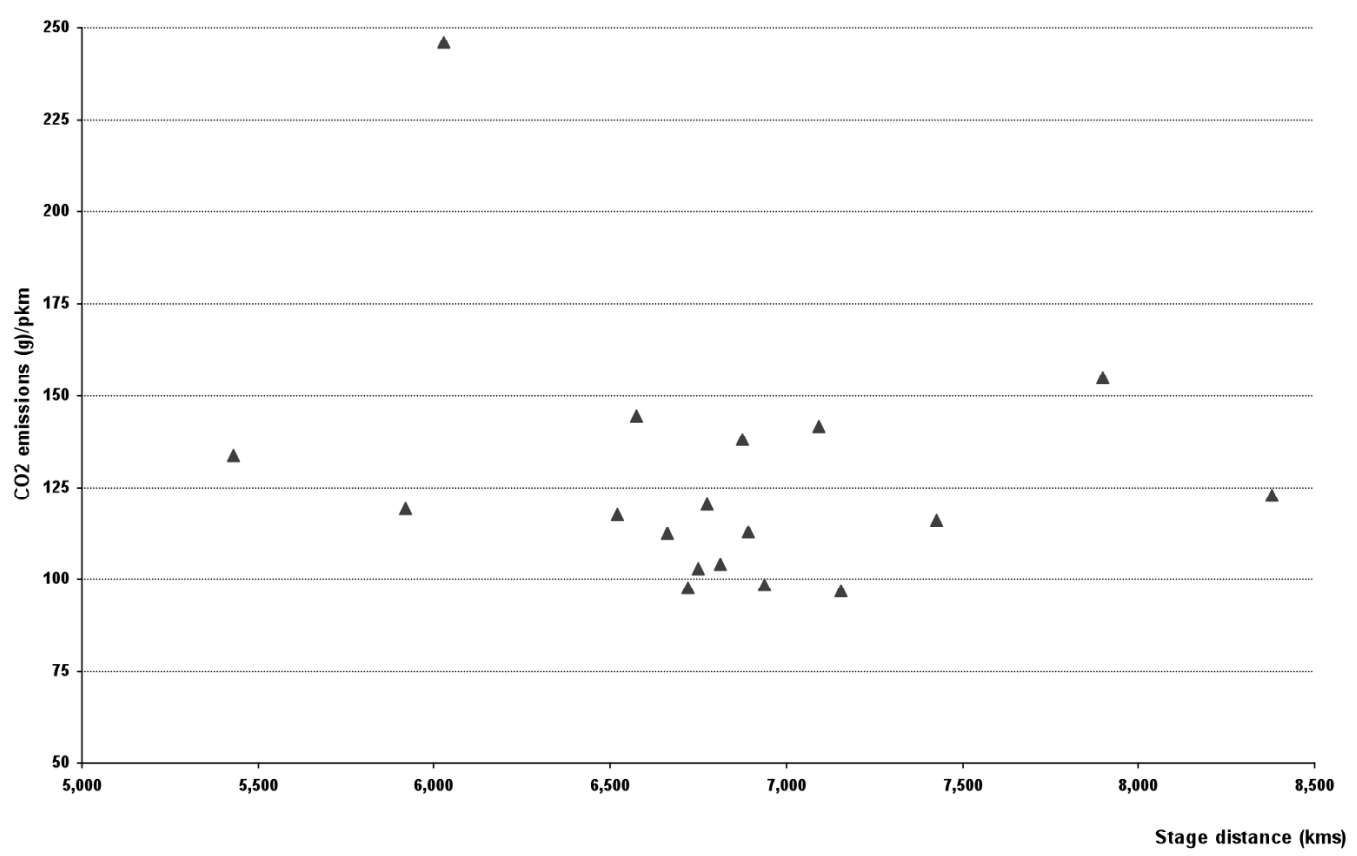

Figure 13 - Estimated average $\mathrm{CO} 2$ emissions by airlines

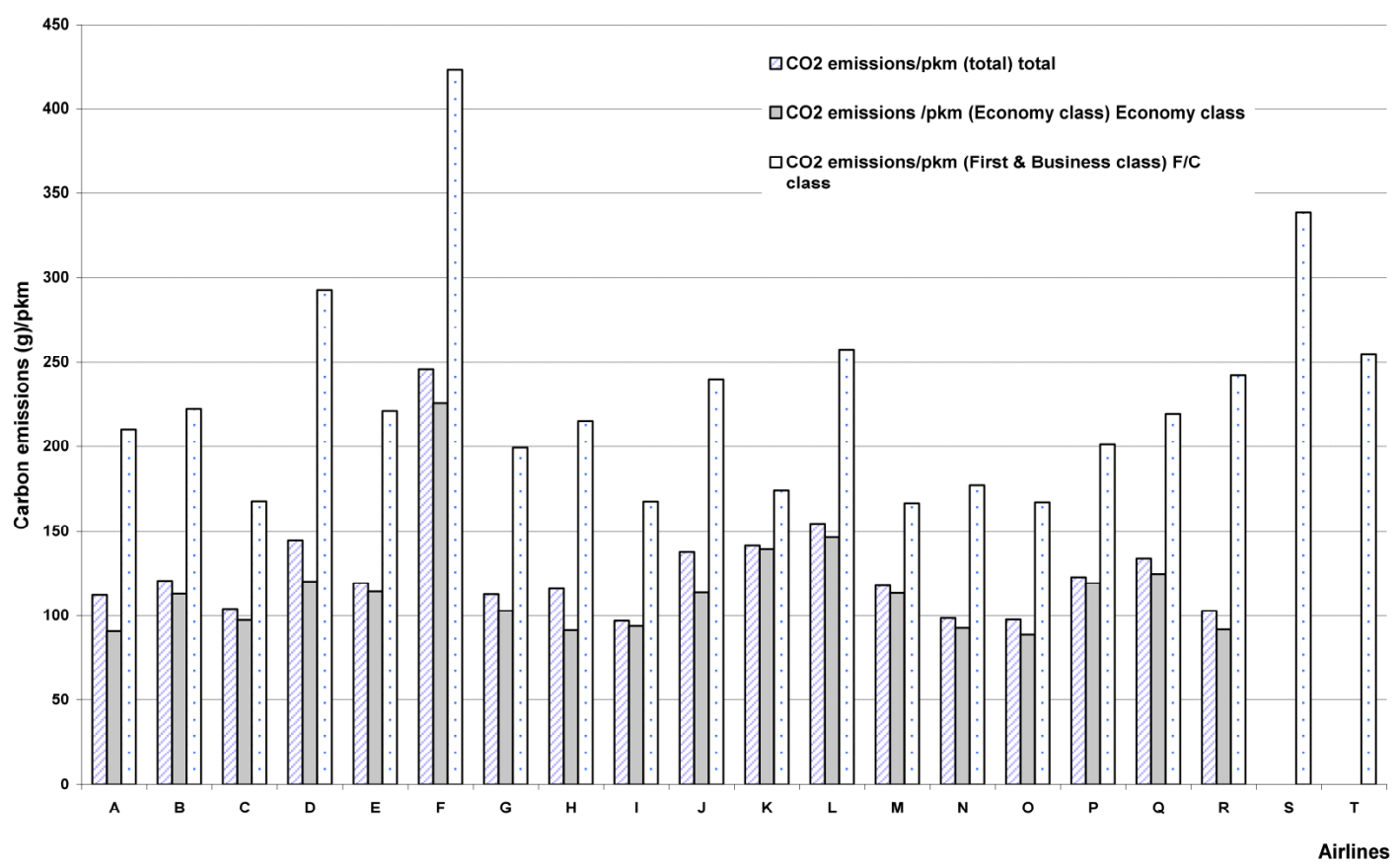


${ }^{\mathrm{i}}$ Load factor: $75 \%$.

ii Load factor: $75 \%$.

iii Calculate assumptions: 78 seats on Dash-8 Q400 and 139 seats on B737-400, load factor: $65 \%$, example route: London-Scotland.

${ }^{\text {iv }}$ Calculate assumptions: 139 seats on B737-400, load factor: $65 \%$, example route: UK-Central Europe.

${ }^{v}$ Calculate assumptions: 346 seats on B747-400, 261 seats on B767-300ER, load factor: $79.9 \%$, example route: UK-Central Europe.

${ }^{\text {vi }}$ Calculate assumptions: 150 seats on $\mathrm{A} 320$, load factor: $70 \%$, example route: Amsterdam-Paris.

${ }^{\text {vii }}$ Calculate assumptions: 150 seats on B737-400, load factor: $70 \%$, example route: Munch-Palma de Mallorca.

viii Calculate assumptions: 340 seats on B777, load factor: $70 \%$, example route: London-Newark. 